\title{
The effect of carbon source on nitrate and ammonium removal from drinking water by immobilised Chlorella sorokiniana
}

\author{
A. Petrovič - M. Simonič
}

Received: 21 August 2014/Revised: 16 November 2014/Accepted: 30 December 2014/Published online: 15 January 2015 (C) Islamic Azad University (IAU) 2015

\begin{abstract}
The feasibility of alginate-immobilised Chlorella sorokiniana for nitrate and ammonium removal from drinking water in regard to carbon source effects was studied in this paper. Three different natural carbon sources were tested in batch experiments with nitrate as nitrogen source: sucrose, grape juice and acacia honey. The nitrate removal efficiencies achieved at $50 \mathrm{mg} / \mathrm{L}$ of initial nitrate concentration under sucrose, grape juice and acacia honey were 93, 99 and $94 \%$, respectively. At $100 \mathrm{mg} / \mathrm{L}$ of nitrate, comparable efficiencies were obtained after approximately 3 days, whilst for acacia honey at $50 \mathrm{mg} / \mathrm{L}$, it took only 2 days of cultivation and 3 days for the other two carbon sources. Grape juice and acacia honey showed better performances than sucrose, which must be linked to their chemical compositions. The study of the impact of biosorbent quantity on nitrate removal efficiency showed that sufficient nitrate removal efficiencies could be achieved with a beads/water ratio of 1:6.7 (v/v) or smaller. In addition, the beads' ages significantly impacted the nitrate removal. The removal of ammonium was studied in the presence of nitrate with acacia honey as carbon source. At the highest concentrations being tested (ammonium$30 \mathrm{mg} / \mathrm{L}$ and nitrate-50 $\mathrm{mg} / \mathrm{L}$ ), ammonium was completely removed in $<3$ days and nitrate by $81 \%$ in 4 days, whereby the suitable beads/water ratio was $1: 5$. The priority of ammonium assimilation was noticed when compared to nitrate. According to the results, the alginateimmobilised $C$. sorokiniana represents a promising tool for the removal of nitrogen from drinking water sources.
\end{abstract}

\footnotetext{
A. Petrovič $(\bowtie) \cdot$ M. Simonič

Faculty of Chemistry and Chemical Engineering, University of Maribor, Smetanova 17, 2000 Maribor, Slovenia

e-mail: aleksandra.petrovic@um.si
}

Keywords Algae $\cdot$ Ammonium · Carbon source . Chlorella sorokiniana $\cdot$ Drinking water $\cdot$ Nitrate

\section{Introduction}

Natural waters contain several nutrients such as ammonium, nitrate and phosphate, which contribute to eutrophication in water bodies. Therefore, the development of efficient treatment processes is currently a worldwide priority. As an alternative biological treatment, 'microalgae' has been proposed for removing these pollutants from water due to its efficiency, ecological safety and low cost (Mallick 2002; Rasoul-Amini et al. 2014). In addition, these microorganisms are able to remove even heavy metals and some other hazardous compounds (Kaonga et al. 2008; Mane and Bhosle 2011).

Nitrogen removal by algae depends on numerous factors: the algae species, media composition and different environmental parameters such as light illumination, $\mathrm{pH}$ and temperature (Abdel-Raouf et al. 2012; Rasoul-Amini et al. 2014). The media composition is highly correlated to nutrient and carbon source availabilities. Algal treatment in the presence of carbon source was extensively studied by Kim et al. (2013a) and some other researchers (Prathima Devi et al. 2013) who reported promising results obtained with glucose. Sugars such as fructose and sucrose were also commonly used for the cultivation of microalgae (Ngangkham et al. 2012; Perez-Garcia et al. 2011a; Sun et al. 2008). Only limited articles report about alternative carbon sources, such as molasses (Leesing and Kookkhunthod 2011; Olguín et al. 2008; Vidotti et al. 2014) and sweet sorghum (Gao et al. 2010).

Anyway, the weakness of algal treatment systems is the harvesting of algal biomass (Mallick 2002); therefore, 
immobilisation technology that entraps the microalgal cells into a matrix can solve this problem (de-Bashan and Bashan 2010). The effectiveness of immobilisation technology in water treatment depends upon many factors: the type of immobilisation matrix, algal species, cell and bead concentrations, type of nitrogen source and type of water (Mallick 2002; Moreno-Garrido 2008). Current applications regarding the performance of immobilisation technology for algal treatment include immobilisations on different natural carriers such as alginate, carrageenan, and chitosan, and furthermore proteins such as gelatin and also synthetic polymers such as polyvinyl alcohol (de-Bashan and Bashan 2010; Moreno-Garrido 2008; Nussinovitch 2010). In order to enhance the properties of such carriers, some research has even focused on the mixtures of their compounds (Cruz et al. 2013). Nevertheless, alginate is still one of the more commonly used polymers for the immobilisation. Its advantages are simple and fast immobilisation, high permeability, non-toxicity and low polymer costs (de-Bashan and Bashan 2010; Moreno-Garrido 2008; Nussinovitch 2010). In regard to the presence of carbon source when using alginate as algae immobilisation technology, only few data are available. Thus, in one study on alginate-immobilised Chlorella sorokiniana, the wastewater was supplemented with sodium acetate (Liu et al. 2012). In another research with $C$. vulgaris immobilised into the same matrix, glucose was used as carbon source (Tam and Wong 2000).

Chlorella sorokiniana, which is known to be capable of growth under autotrophic, heterotrophic and mixotrophic conditions, is an effective species for nutrients' removal and immobilisation (Kim et al. 2013b; Prathima Devi et al. 2013). Current studies on $C$. sorokiniana included investigations on its performance for nutrients removal from polluted waters (de-Bashan et al. 2004; Lizzul et al. 2014), some focused on its potential for biofuel production (Zheng et al. 2013), and others examined growth conditions (Kim et al. 2013b; Kumar and Das 2012). However, the application of $C$. sorokiniana for wastewater treatment processes was only efficiently implemented in rare studies. The usefulness of alginate-immobilised $C$. sorokiniana for the removal of nitrogen and phosphate from a synthetic wastewater was examined by Liu et al. (2012) and Kim et al. (2013a). De-Bashan et al. (2008) studied its growth on wastewaters under extreme conditions, and the potential of this algae for using wastewater from fish processing as a growth medium in symbiosis with aerobic bacteria was evaluated by Riaño et al. (2012). A combination of $C$. sorokiniana and a growth-promoting bacterium A. brasilense, co-immobilised in alginate beads, was also developed to remove phosphorus and nitrogen from wastewater (de-Bashan et al. 2004; Hernandez et al. 2006). As $C$. sorokiniana is, according to above-mentioned papers, a suitable strain for water treatment and has the capability of utilising multiple carbon sources even under mixotrophic conditions (Lizzul et al. 2014; Qiao et al. 2009), it was the proper choice for the present study.

This study describes various attempts regarding the removal of nitrate and ammonium from drinking water by C. sorokiniana immobilised in Ca-alginate. The attention was directed mainly towards the natural carbon sources, as no papers regarding the performances of acacia honey or grape juice could be found in the literature. Thus, the hypothesis was set that the performance of $C$. sorokiniana could be improved in the presence of natural carbon sources due to diversities of their compositions which could positively impact the algae. Within this context, the effectiveness of selected carbon sources was evaluated in comparison with their absence and the impact was investigated of immobilised algal bead concentrations on nutrient removal. This work was implemented within the research project between 2012 and 2014 at the Faculty of Chemistry and Chemical Engineering at the University of Maribor, Slovenia.

\section{Materials and methods}

Algal culture and immobilisation of cells

The cells of $C$. sorokiniana were obtained from the local algal technology centre (AlgEn, Slovenia) and cultivated in Bold's basal growth media at room conditions (Bischoff and Bold 2003). After a 10-day cultivation when the microalgae were acclimatised, the algal cells were harvested by centrifugation (at 3,500 rpm for $15 \mathrm{~min}$ ).

Immobilised algal beads were prepared by entrapping cells of $C$. sorokiniana in an alginate matrix according to the following steps (Ruiz-Marin et al. 2010): the harvested cells were re-suspended in distilled water to form a concentrated algal suspension, which was then mixed with $4 \%$ sodium alginate (Fluka) solution at a 1:1 volume ratio to yield a mixture of $2 \%$ algal alginate suspension. The mixture was then dropped into a $2 \%$ calcium chloride (Merck) solution using a $25-\mathrm{mL}$ burette. The drops of algal alginate solution gelled into small alginate beads (with cell numbers of around $6.5 \times 10^{5}$ cells bead $^{-1}$ ) upon contact with calcium chloride solution $(2 \%)$. The solution was stirred to prevent aggregation of the algal cell entrapped in alginate beads. Immobilised algal beads were then stored in a calcium chloride solution for approximately $4 \mathrm{~h}$, rinsed with saline solution $(0.85 \% \mathrm{NaCl})$ and subsequently with distilled water. The beads were then transferred to the algal growth medium and were incubated under room conditions for 3 days. After short incubation, the beads with immobilised algal cells were removed from the medium and 
washed twice with saline solution $(0.85 \%)$ and finally with distilled water.

\section{Characterisation of adsorbent}

The water content of the algal beads was determined after drying a certain quantity of weighed sample in a vacuum oven at $60^{\circ} \mathrm{C}$ until constant weight was achieved (for approx. $48 \mathrm{~h}$ ). The FTIR spectra of the immobilised alginate beads and blank beads were obtained using an FTIR spectrophotometer (FTIR Shimadzu IRAffinity-1, Japan). The dry sample of immobilised algae was mixed with $\mathrm{KBr}$ (at a ratio 1:30) and pressed into tablet form. The FTIR spectrum was then recorded. The same procedure was used for blank beads.

The specific surface area, the pore sizes and the pore volume of the $C$. sorokiniana immobilized alginate beads were measured by a surface area apparatus according to the following procedure. After obtaining a hydrogel, the alcogels were formed by solvent exchange using $100 \%$ ethanol. The hydrogel spheres were dehydrated by immersions within a series of successive ethanol-water baths of increasing ethanol concentrations $(10,30,50,70$, 90 and $100 \%$ ). Ethanol was then removed by supercritical drying with carbon dioxide at $40{ }^{\circ} \mathrm{C}$ and 100 bar during 6-7 h. Gas adsorption measurements were applied for defining the surface area and pore-size distributions of the material in a Micromeritics ASAP 2020MP at $-196{ }^{\circ} \mathrm{C}$ after degassing the sample at $70{ }^{\circ} \mathrm{C}$ for $660 \mathrm{~min}$ under vacuum, until obtaining a stable $10 \mu \mathrm{m} \mathrm{Hg}$ pressure. The BET (Brunauer, Emmett and Teller) equation was used for determining the surface area by assuming a $0.162 \mathrm{~nm}^{2} /$ molecule as the molecular area of $\mathrm{N}_{2}$.

\section{Experimental procedures}

The experiments were performed by placing $C$. sorokiniana immobilised algal beads into glass bioreactors with drinking water. For the experiments with nitrate as nitrogen source, the drinking water was spiked with $\mathrm{KNO}_{3}$ (Fluka) in order to achieve concentrations of 20 , 50 or $100 \mathrm{mg} / \mathrm{L}$ of nitrate ions. In the case of the experiments with ammonium, $\mathrm{NH}_{4} \mathrm{Cl}$ (Fluka) was added to the water sample containing nitrate, whereby the initial concentrations of ammonium ions used were 10 or $30 \mathrm{mg} / \mathrm{L}$. The mixing within the reactors (at intervals) was provided by a magnetic stirrer. All experiments were carried out under room conditions because it was desirable to realise almost natural conditions. Therefore, the temperature, $\mathrm{pH}$ and luminosity were unregulated. The hydraulic retention time of water was from 2 up to 7 days depending on each experiment. After that time, the water in the reactors was replaced
Table 1 Experimental conditions for performed experiments

\begin{tabular}{|c|c|c|c|c|c|}
\hline $\begin{array}{l}\text { Carbon } \\
\text { source }\end{array}$ & $\begin{array}{l}\text { Carbon source } \\
\text { concentration } \\
(\mathrm{g} / \mathrm{L})\end{array}$ & $\begin{array}{l}\mathrm{\gamma NO}_{3}^{-} \\
(\mathrm{mg} / \mathrm{L})\end{array}$ & $\begin{array}{l}\gamma \mathrm{NH}_{4}{ }^{+} \\
(\mathrm{mg} / \mathrm{L})\end{array}$ & $\begin{array}{l}\text { Ratio beads/ } \\
\text { water (v/v) }\end{array}$ & $\begin{array}{l}\text { Exp. } \\
\text { labe }\end{array}$ \\
\hline - & - & $20,50,100$ & - & $1: 10$ & $\mathrm{~N}$ \\
\hline Sucrose & 0.5 & $20,50,100$ & - & $1: 10$ & $\mathrm{~S}$ \\
\hline $\begin{array}{l}\text { Acacia } \\
\text { honey }\end{array}$ & 0.5 & $20,50,100$ & - & $\begin{array}{l}1: 4 \\
1: 6.7\end{array}$ & $\begin{array}{l}\mathrm{HA} \\
\mathrm{HB}\end{array}$ \\
\hline $\begin{array}{l}\text { Acacia } \\
\text { honey }\end{array}$ & 0.25 & $20,50,100$ & - & $\begin{array}{l}1: 4 \\
1: 6.7\end{array}$ & $\begin{array}{l}\mathrm{HA} \\
\mathrm{HB}\end{array}$ \\
\hline $\begin{array}{c}\text { Grape } \\
\text { juice }\end{array}$ & 0.5 & $20,50,100$ & - & $\begin{array}{l}1: 10 \\
1: 6.7 \\
1: 6.7\end{array}$ & $\begin{array}{l}\text { GA } \\
\text { GB } \\
\text { GC }\end{array}$ \\
\hline $\begin{array}{l}\text { Grape } \\
\text { juice }\end{array}$ & 0.25 & $20,50,100$ & - & $\begin{array}{l}1: 10 \\
1: 6.7 \\
1: 6.7\end{array}$ & $\begin{array}{l}\text { GA } \\
\text { GB } \\
\text { GC }\end{array}$ \\
\hline - & - & 20 & 10 & $1: 6.7$ & NB \\
\hline $\begin{array}{l}\text { Acacia } \\
\text { honey }\end{array}$ & 0.25 & 50 & 10 & $1: 6.7$ & $\mathrm{HB}$ \\
\hline $\begin{array}{l}\text { Acacia } \\
\text { honey }\end{array}$ & 0.25 & 50 & 30 & $\begin{array}{l}1: 6.7 \\
1: 5\end{array}$ & $\begin{array}{l}\mathrm{HB} \\
\mathrm{HC}\end{array}$ \\
\hline
\end{tabular}

by fresh drinking water containing appropriate amounts of substances added according to the preferred experimental conditions.

Experiments on removal of nitrate (at initial concentrations of 20,50 and $100 \mathrm{mg} / \mathrm{L}$ ) without the addition of external carbon source were conducted at beads/water ratio of $1: 10(\mathrm{v} / \mathrm{v})$ and were denoted with $\mathrm{N}$ (Table 1). The repetitions of the same measurement on the figures were indicated by Arabic numerals.

In the study on the impact of the external carbon source on the nitrate removal, three different external carbon sources were tested: sucrose (samples marked as $\mathrm{S})$, acacia honey $(\mathrm{H})$ and grape juice $(\mathrm{G})$. Sucrose was used in the form of white table sugar. The experiments with sucrose were conducted at 20,50 and $100 \mathrm{mg} / \mathrm{L}$ of nitrate with the carbon source concentration of $0.5 \mathrm{~g} / \mathrm{L}$ and beads/water ratio of 1:10. The grape juice and acacia honey were used as carbon sources due to their high contents of fructose and glucose, as these two sugars can be more easily assimilated by algae. The pasteurised grape juice prepared from white grapes contained about $24 \%$ of sugar. The acacia honey was delivered from local producers. For studying the effects of the carbon sources, two different concentrations of these two carbon sources were tested (at three different initial nitrate concentrations), 0.5 and $0.25 \mathrm{~g} / \mathrm{L}$, respectively. The above-mentioned concentrations of carbon sources are much lower than the amounts that are usually applied in microalgae growth cultivation, but on the other hand, it must be considered that in these experiments, drinking water was used and therefore some additional 
regulations had to be taken into account (i.e. the regulations for COD concentrations). In those experiments, different concentrations of the alginate beads (i.e. different beads/water ratios) were also used in order to reach the best performance regarding nitrate removal. These samples were, besides the above-mentioned labels, additionally labelled with letters A, B and C (for details, see Table 1). For each set of experiments, new algal beads were used except in the case of sample $\mathrm{C}$ with grape juice as carbon source. Herein, the impacts of the beads' ages on nitrate removal efficiency were studied (with beads/water ratio of 1:6.7), and the beads that were used for this purpose had already been used in the experiment with acacia honey; therefore, their ages were approximately 4-5 weeks.

The first experiment on the combination of ammonium and nitrate in the absence of carbon source (marked as $\mathrm{NB})$ was conducted at 10 and $20 \mathrm{mg} / \mathrm{L}$ of each nitrogen source, respectively. In the second experiment (labelled with $\mathrm{HB}$ ), with the same concentration of ammonium as before, the nitrate concentration was set at $50 \mathrm{mg} / \mathrm{L}$. Both experiments were performed at beads/water ratio of 1:6.7. The last experiment with the highest nitrogen source concentrations used (i.e. $30 \mathrm{mg} / \mathrm{L}$ for ammonium and $50 \mathrm{mg} / \mathrm{L}$ for nitrate) was performed at two different beads/water ratios, whereby the first one was the same as in first two experiments and another was 1:5 (sample HC). Acacia honey served as carbon source in the last two experiments (with the concentration of $0.25 \mathrm{~g} / \mathrm{L}$ ). Otherwise, all the details of the experimental conditions are given in Table $1(\gamma$ represents the concentration of each parameter in $\mathrm{mg} / \mathrm{L}$ ).

\section{Analytical procedures}

The samples for analyses were collected daily and filtered in order to exclude solids that may be present in the water. Several analyses were performed in order to follow the experiment's performance. The samples were diluted before analysis if necessary. Analyses of ammonium, nitrate and nitrite were conducted spectrophotometrically (DIN 38 406-E5-1:1983; ISO 6777:1984; ISO 7890-1:1986) by using an Agilent 8453 UV-Visible Spectrophotometer at 655,324 and $540 \mathrm{~nm}$ wavelengths, respectively. The calculations for all three analyses were made according to the previously prepared calibration curve. The chemical oxygen demand (COD) was determined by a volumetric method using titration with $\mathrm{KMnO}_{4}$ (determination of the permanganate index) according to ISO standard 8467:1993 (ISO 8467:1993). The number of algal cells in the beads was counted using a Neubauer hemocytometer after dissolving the alginate beads in $0.1 \mathrm{M}$ trisodium citrate solution (Mehta and Gaur 2001).

\section{Results and discussion}

\section{Characterisation of adsorbent}

Some basic characteristics of the algal beads were determined in order to characterise the adsorbents before being used in the experiments. One of the numerous factors that impact the performances of algae and the efficiency of nutrients removal is bead size. The higher the diameters of beads, the higher the removal efficiency. Abdel Hameed (2007) reported that bigger sized $C$. vulgaris immobilised algal beads (4 and $6 \mathrm{~mm}$ ) were more efficient than smaller ones $(2.8 \mathrm{~mm})$, and as the first two gave similar results, it was concluded that continuous increase in bead size would not necessarily result in better performance of nutrients removal. As a bead size of around 2-4 mm was likewise used in some other studies (Cruz et al. 2013; de-Bashan et al. 2004; Liu et al. 2012), a similar size of $C$. sorokiniana immobilised alginate beads was chosen for this study. Thus, the diameters of algal beads measured herein were within the range of $3.5 \pm 0.5 \mathrm{~mm}$. The water content of the beads was determined after drying the sample until constant weight and was found to be around $98 \%$. The specific surface area of the $C$. sorokiniana immobilised alginate beads was measured at $562.0034 \mathrm{~m}^{2} / \mathrm{g}$. The pore sizes of the beads amounted to $14.4130 \mathrm{~nm}$, and the pore volume was $1.8421 \mathrm{~cm}^{3} / \mathrm{g}$. Since calcium chloride acted as hardening agent of the alginate beads, its concentration, besides alginate concentration, significantly influences the alginate beads properties such as their structure, mechanical strength and porosity. The concentrations used in this study ( $2 \%$ for $\mathrm{CaCl}_{2}$ and $2 \%$ for algae-alginate suspension) are in accordance with those more frequently used, as they could provide more promising results. Usually, the higher the concentration of alginate and $\mathrm{Ca}^{2+}$ in the mixture, the stronger the gel. On the other hand, in some studies on the impact of different concentrations of $\mathrm{CaCl}_{2}$ and alginate on the deterioration of alginate beads, attempts to enhance the strength of the beads have failed with higher concentrations of these two chemicals (Cruz et al. 2013).

The surface chemical characteristic, i.e. functional groups of the immobilised algal beads, was identified using FTIR spectroscopy, which is widely used for providing information on a range of vibrations of active functional groups in several biological specimens. The FTIR spectra of alginate beads and alginate beads immobilised with $C$. sorokiniana are represented in Fig. 1. The broad and strong band observed at $3,402 \mathrm{~cm}^{-1}$ corresponded to the stretching of hydroxyls $(-\mathrm{OH})$. In this area, the $-\mathrm{NH}$ groups of algal biomass could also appear. The absorption peaks at 2,924-2,854 $\mathrm{cm}^{-1}$ could be attributed to the $\mathrm{C}-\mathrm{H}$ aliphatic functional group. The band at $1,419 \mathrm{~cm}^{-1}$ represented $\mathrm{C}-\mathrm{C}$ stretching vibrations of the aromatic ring, and the peaks 


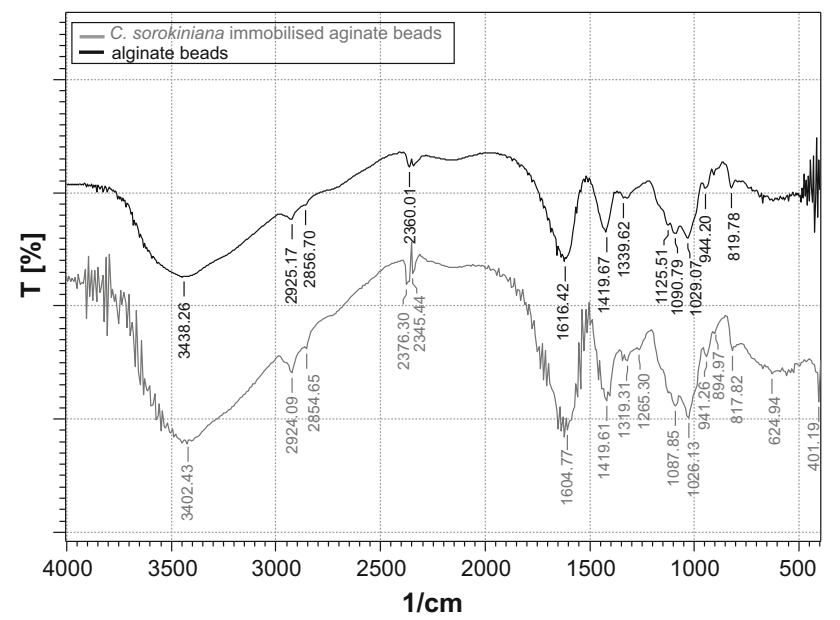

Fig. 1 FTIR spectra of alginate beads and alginate beads immobilised with $C$. sorokiniana

observed at 1,087 and $1,026 \mathrm{~cm}^{-1}$ were indicative of the presence of $\mathrm{C}-\mathrm{O}$ stretching alcohols, carboxylic acids and carbohydrate of polysaccharides. The bands in the regions of 1,265 and $1,319 \mathrm{~cm}^{-1}$ may be attributed to the $\mathrm{C}-\mathrm{N}$ stretch of aromatics or $\mathrm{C}-\mathrm{O}$ stretch of alcohols and carboxylic acids. By means of the above functional groups, the presence of alginate could be confirmed. The band at $1,604 \mathrm{~cm}^{-1}$ can be assigned to $\mathrm{N}-\mathrm{H}$ bending of amines of algal biomass. When comparing this spectrum with the spectrum of alginate beads without immobilised cells of algae, several similarities could be seen. However, stronger peaks were observed in the case of immobilised algae and peaks shifted slightly.

Removal of nitrate without addition of external carbon source

Nitrogen as one of the more important components affecting microalgae growth can be metabolised by algae via the absorption of nitrate, ammonia and urea (Christenson and Sims 2011; Shi et al. 2000). Nitrate removal by alginateimmobilised $C$. sorokiniana at three different initial nitrate concentrations 20, 50 and $100 \mathrm{mg} / \mathrm{L}$ is shown in Fig. 2a ( $y$ axis represents the concentrations of each parameter in $\mathrm{mg} / \mathrm{L}$, and $x$ axis represents the time in days). All experiments were performed at the same microalgal bead concentration (beads/water volume ratio 1:10). From Fig. 2a, it could be seen that the initial nitrate concentrations strongly affected the performances of nitrate removal. The higher the initial concentration, the longer the removal time. At the lowest initial nitrate concentration $(20 \mathrm{mg} / \mathrm{L})$, removal efficiency of $90.73 \%$ was achieved after $24 \mathrm{~h}$. By increasing the nitrate concentration to approximately twice the removal time prolonged it for up to several days, but the nitrate was still incompletely removed. Even worse results could be seen at $100 \mathrm{mg} / \mathrm{L}$ of nitrate, as after 6 days, only half of the initial amount of nutrient was assimilated. Although nitrite was not added to the initial water sample, it could have been formed during the nitrate removal process, as nitrate assimilation by microalgae is performed over two phases. In the first step, nitrate reductase reduces nitrate into nitrite by using reduced pyridine nucleotides as physiological electron donors. Afterwards, nitrite is reduced to ammonium by nitrite reductase, whereas in a reaction that involves the transfer of six electrons, ferredoxin is used as the electron donor (Awasthi 2005; Perez-Garcia et al. 2011b). In accordance with the reactions, the nitrite concentrations at the beginning of the experiment were low, then an increase was observed, and then they slowly dropped to their final values (Fig. 2b).

Despite $C$. sorokiniana being reported to have a higher capacity for nutrient removal than other algae (Liu et al. 2012), the results obtained in the experiments without external carbon source herein were disappointing. The concentration of algal cells decreased by more than half, which could also be seen in the colours of the beads which were closer to yellow than the green colour. The main reason for such results was probably the absence of carbon source that obviously plays a crucial role in the nutrients' removal and microalgal growth $\left(\mathrm{CO}_{2}\right.$ from air is therefore not enough). Similar had already been noted for $C$. vulgaris cultivation, as no growth occurred without a carbon source, whilst growth was observed with a carbon source (PerezGarcia et al. 2011a). However, the tested water sample did not contain any additional phosphorus and this also could have impacted on the $C$. sorokiniana growth. Some authors postulated that nitrate consumption inhibition could occur due to the presence of nitrite (Moreno-Garrido 2008).

Finally, it was concluded that drinking water spiked only with nitrate is an unsuitable media for the growth of algae; therefore, in the following steps, different natural carbon sources were used next to the nitrate.

The impact of the external carbon source on the removal of nitrate

Microalgae require all three major nutrients for their growth: carbon, nitrogen and phosphorus (Christenson and Sims 2011; Shi et al. 2000). Thus, in this paper, the potential usefulness of three natural carbon sources was studied: sucrose, grape juice and acacia honey. Nitrate and nitrite removal by alginate-immobilised $C$. sorokiniana in the presence of sucrose as a carbon source $(0.5 \mathrm{~g} / \mathrm{L})$ is shown in Fig. 2c, d, respectively. At an initial nitrate concentration of $50 \mathrm{mg} / \mathrm{L}$, nitrate was removed in 3 days in $92.55 \%$ and at $100 \mathrm{mg} / \mathrm{L}$ for approx. $88.22 \%$ in 4 days. However, at lower nitrate concentrations, the nitrites were more efficiently removed than at higher concentrations. In 

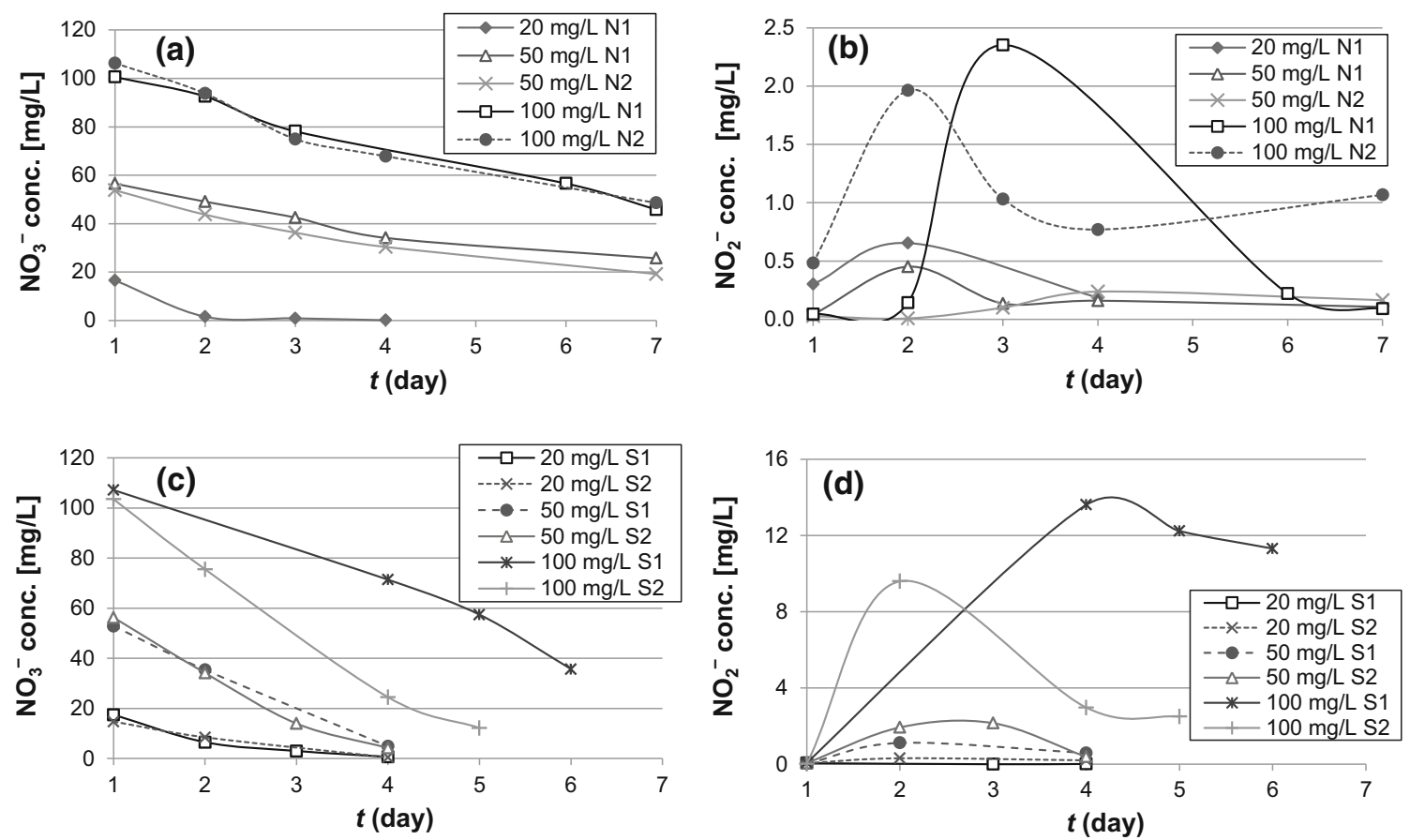

Fig. 2 Nitrate and nitrite removal from drinking water by alginate-immobilised C. sorokiniana at initial nitrate concentrations 20,50 and $100 \mathrm{mg} / \mathrm{L}$ : in the absence of external carbon source $(\mathbf{a}, \mathbf{b})$ and in the presence of $0.5 \mathrm{~g} / \mathrm{L}$ sucrose $(\mathbf{c}, \mathbf{d})$

comparison with experiments without external carbon source, sucrose enhanced the nitrate removal and the removal times were significantly shorter. This suggested that $C$. sorokiniana assimilated a part of the sucrose that was probably hydrolysed to glucose and fructose. However, papers regarding sucrose performance as carbon source for algae cultivation are quite inconclusive. Some research claims that microalgae do not have invertase to assimilate sucrose; then, others in contrast to them indicated positive results when using sucrose. For instance, Perez-Garcia et al. (2011a) found that supplementation with sucrose, Ca-acetate and vinegar supported meagre multiplication of $C$. vulgaris, whilst the absence of a carbon source completely inhibited multiplication. In contrast, during research into hydrogen production by immobilised C. vulgaris, sucrose produced the greater amounts of hydrogen from all carbon sources (Rashid et al. 2013). For the same algae species, it was also found that hydrolysed sucrose supported microalgae growth, but with non-hydrolysed sucrose, cell growth was not observed (Vidotti et al. 2014). Low specific growth rates when using sucrose were also reported for $C$. zofingiensis (Sun et al. 2008). On the other hand, sucrose acted positively with $C$. sorokiniana (Ngangkham et al. 2012).

The application of acacia honey as carbon source for immobilised algae regarding the existing literature has not been reported to date; therefore, two initial concentrations of honey were tested (Fig. 3). The first concentration was the same as the sucrose concentration $(0.5 \mathrm{~g} / \mathrm{L})$, another was reduced to $0.25 \mathrm{~g} / \mathrm{L}$, as very high COD concentrations were observed in the final water samples. As seen from Fig. 3 at both carbon concentrations, removal of nitrate was more successful than with sucrose. Moreover, the nitrite was formed only in small quantities, but it must be considered that both samples (A and B) contained higher amounts of beads than were used in the experiment with sucrose (sample A ratio 1:4 and sample B ratio 1:6.7). Otherwise, no deleterious effects on the immobilised algae were observed for honey during this experiment; in fact the opposite occurred: the algae were even greener and the cell concentration increased up to $2.5 \times 10^{6}$ cells/bead. It also seems that the algae had not been considerably affected because of phosphorus absence. Moreover, honey at low levels contains mineralic phosphorus and phosphoric acid; thus, phosphorus might be indirectly available to algae.

The advantage of honey is therefore its complex composition as it contains several components that could positively impact algae growth. The main compounds of honey are sugars, mainly fructose and glucose, which together represents about $85-95 \%$ of all carbohydrates in honey (Božnar 2003). The remaining carbohydrates include maltose, sucrose and others. The assimilation of glucose that highly depends on the type of nitrogen source begins with a phosphorylation of hexose, yielding glucose-6phosphate, which is then readily available for algae (PerezGarcia et al. 2011b). In addition, more than $85 \%$ of the glucose is assimilated and converted to oligo-(mainly sucrose) and polysaccharides (mainly starch). On the other 

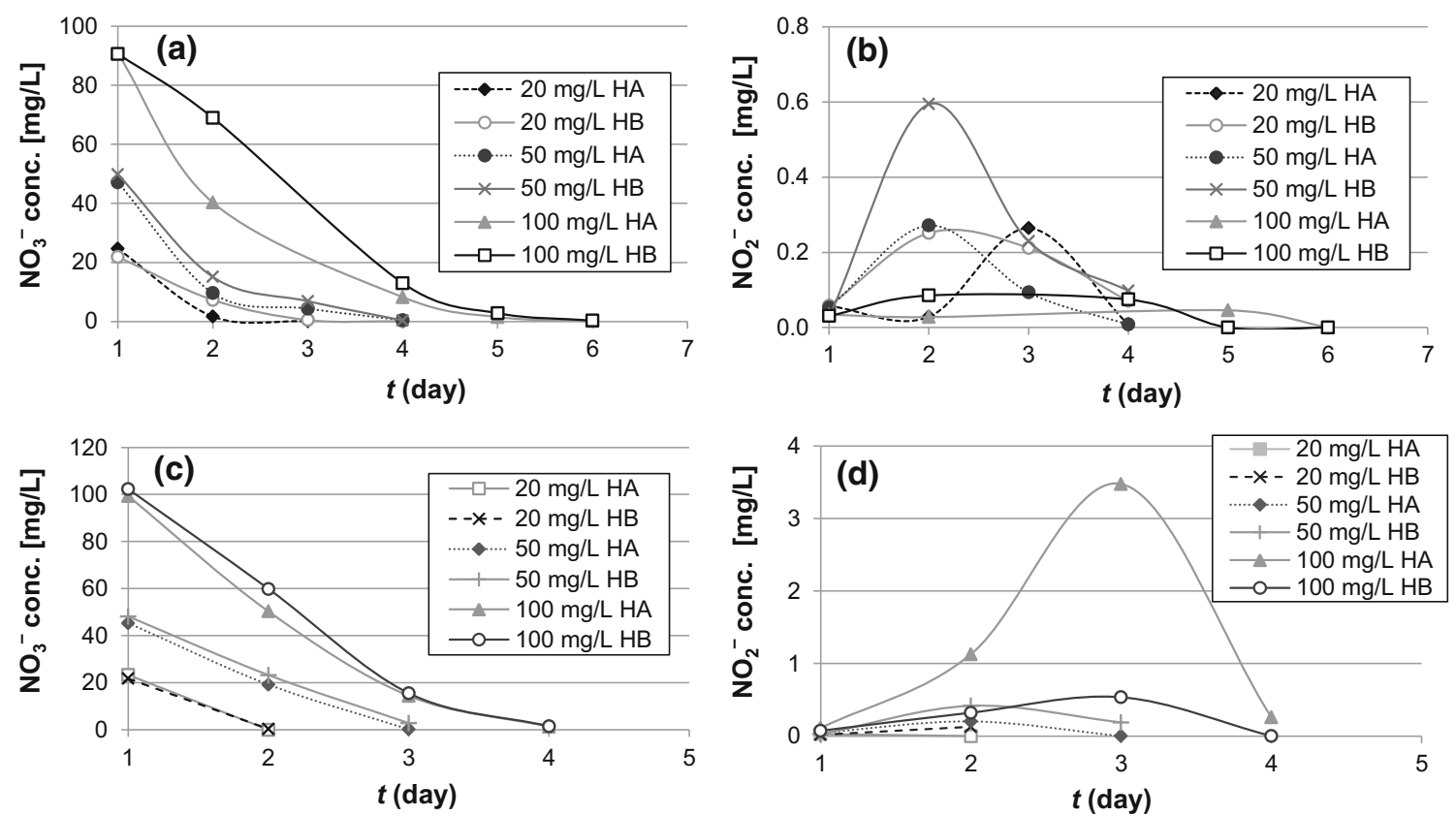

Fig. 3 Nitrate and nitrite removal by alginate-immobilised C. sorokiniana in the presence of acacia honey as carbon source at concentrations of $0.5 \mathrm{~g} / \mathrm{L}(\mathbf{a}, \mathbf{b})$ and $0.25 \mathrm{~g} / \mathrm{L}(\mathbf{c}, \mathbf{d})$, respectively

hand, sucrose is a double sugar (disaccharide) and must be firstly degraded into simple sugars before it can be involved in the metabolism. Therefore, the metabolism of sugars in honey is faster than in sucrose alone. Honey also contains several other compounds (Božnar 2003) such as vitamins, minerals ( $\mathrm{Ca}, \mathrm{Mg}, \mathrm{P}, \mathrm{K}, \mathrm{Fe}, \mathrm{Na} \ldots)$, organic acids, water etc., and it is well known that some green algae can grow heterotrophically, making use of sugars, amino acids and organic acids (Sun et al. 2008). Ngangkham et al. (2012) in his investigation confirmed that the additions of different substrates (amino acids, carbon sources, vitamins), along with reducing agents, may enhance the lipid quality and productivity in mixotrophic cultures of $C$. sorokiniana. They also reported that fructose, glucose and sucrose substrates enhanced chlorophyll up to the eighth day of growth $C$. sorokiniana. Fructose was suitable as carbon source for the heterotrophic growth of C. zofingiensis, but the algal cells demonstrated a slightly lower specific growth rate and dry biomass than that with glucose (Sun et al. 2008). On the other hand, cultivation of $C$. vulgaris with fructose resulted in cell death, whilst this strain was unable to consume fructose (Vidotti et al. 2014).

The third set of experiments was implemented using grape juice (Fig. 4). Fruit juices, which are rich in a number of sugars, are used as carbon sources particularly in the conventional biological treatment of different industrial wastes with activated sludge, but in the case of algae, their use is less frequent. However, grape juice in accordance with obtained results proved to be a promising carbon source (Fig. 4) at an initial concentration of juice of
$0.5 \mathrm{~g} / \mathrm{L}$ as well as at lower concentrations $(0.25 \mathrm{~g} / \mathrm{L})$. By increasing the nitrate concentration, the differences between samples A and B increased due to the different beads' concentrations. Higher nitrate concentrations apparently demand a greater number of $C$. sorokiniana cells and subsequently higher bead concentrations. In regard to nitrite, the comparison of grape juice with honey revealed slightly increased formations of nitrites, but the values were still lower than with sucrose. This could be attributed to different amounts of available COD to algae. Although the same initial concentrations of carbon sources were added to the water, the COD values in the samples with grape juice were lower regarding honey, possibly due to the different chemical composition and higher water content (grape juice contains approx. $70-80 \%$ of water, whilst honey around $17 \%$ ). Higher concentrations of grape juice could still be added, but on the other hand, the COD values are desired to be as low as possible.

The chemical compositions of honey and grape juice concerning sugars are quite similar as the main sugars in the grape juice are also glucose and fructose (ratio close to 1:1), whilst amongst all other sugars, sucrose prevails. The grape juice also contains organic acids, minerals, nitrogen compounds, water, etc. (Bizaj 2006). Therefore, the assimilation process of both substrates should be close to each other. For example, the transportation of one of the main sugars of these two carbon sources, i.e. glucose in the cells of Chlorella, is carried out in the same way: via an active hexose/proton $\left(\mathrm{H}^{+}\right)$symport system. Thus, glucose is assimilated mainly through the 

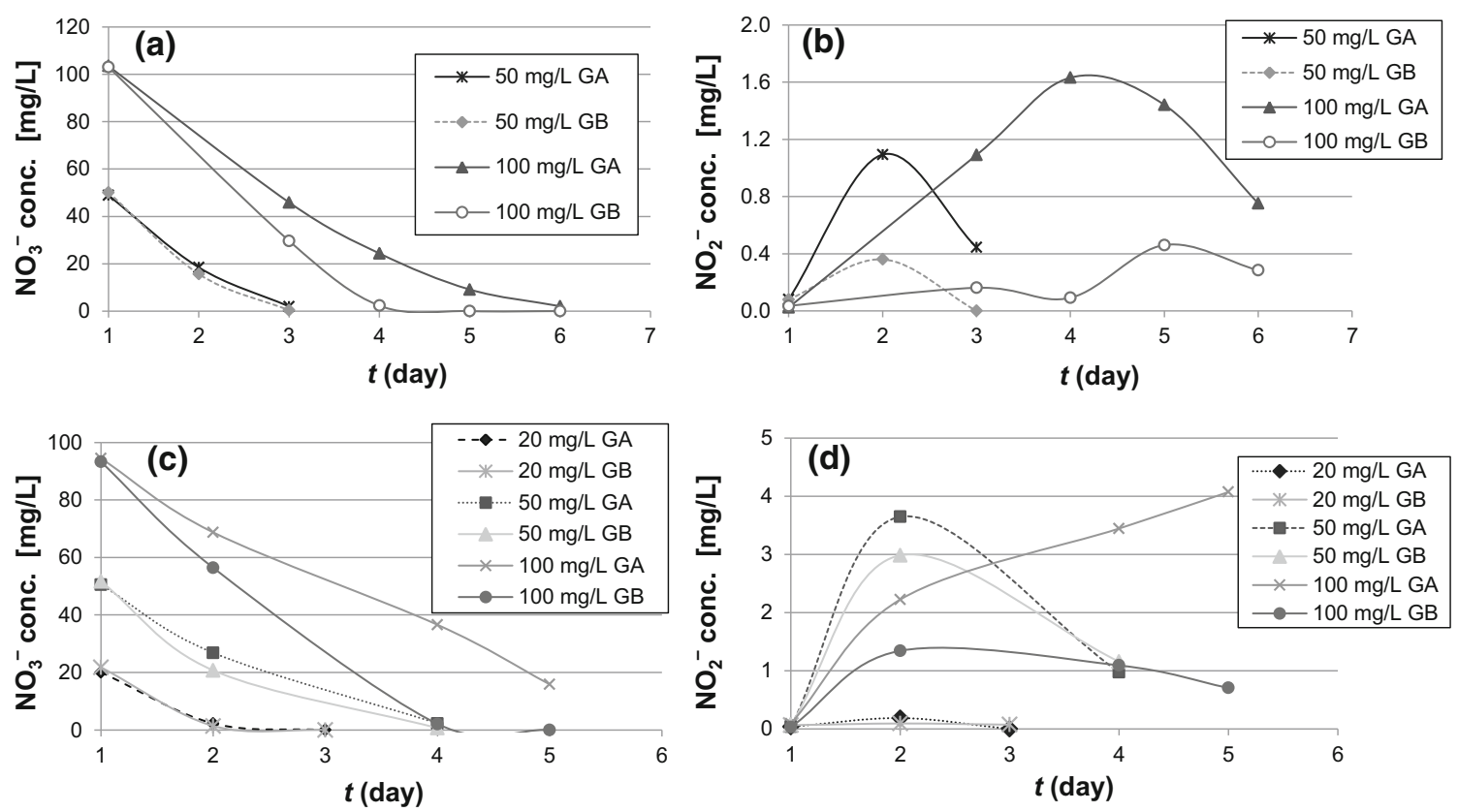

Fig. 4 Nitrate and nitrite removal by alginate-immobilised $C$. sorokiniana in the presence of grape juice as carbon source at concentrations of $0.5 \mathrm{~g} / \mathrm{L}(\mathbf{a}, \mathbf{b})$ and $0.25 \mathrm{~g} / \mathrm{L}(\mathbf{c}, \mathbf{d})$, respectively

pentose phosphate pathway, and the induction of the above-mentioned transporter could be reached by glucose and fructose, but not by pentoses or sucrose (Perez-Garcia et al. 2011b; Sun et al. 2008). However, higher growth rates were obtained with glucose than with any other substrate, but the inhibition of $C$. sorokiniana has been reported when glucose concentrations exceeded $5 \mathrm{~g} / \mathrm{L}$ (Perez-Garcia et al. 2011b).

Otherwise, comparison between the achieved results for grape juice from the previous literature is almost impossible in practice, as no papers connected with its performance could be found. Only the already mentioned studies on glucose and fructose were available.

The $\mathrm{pH}$ values in all experiments with nitrate as nitrogen source were alkaline most of the time: the average for the initial values was $7.36 \pm 0.34$ and for the final one $9.06 \pm 0.89$. As could be noticed, the values slowly rose during the experiments, and an increase was observed of approximately one to two degrees. This is in accordance with one of the earlier papers, where nitrate consumption in the batch culture of $C$. sorokiniana likewise led to an increase in pH (Zheng et al. 2013). Otherwise, microalgae mostly maintain neutral or slightly alkaline $\mathrm{pH}$, as enzymes such as nitrate reductase may become inactive within strongly acidic or strongly alkaline mediums, which are then reflected in nitrate uptake. Moreover, the $\mathrm{pH}$ of the medium could also affect the carbon uptake, whereby the activity of hexose $/ \mathrm{H}^{+}$ symporter proteins responsible for its metabolism could be reduced (Tanner 2000; Zheng et al. 2013). The explanation for $\mathrm{pH}$ rising when using nitrate as nitrogen source may be found in the production of hydroxyl ions during nitrogen metabolism; furthermore, the uptake of $\mathrm{CO}_{2}$ from dissolved bicarbonate during photosynthesis could also be reflected in $\mathrm{pH}$ increase under nitrate growth conditions (Lizzul et al. 2014). Besides the type of nitrogen source, the $\mathrm{pH}$ value is also connected with the initial concentration of the chosen nitrogen source. Thus, at higher initial nitrate concentrations, the final $\mathrm{pH}$ values were higher than those at lower nitrate concentrations, as due to the higher initial nitrogen concentration, the removal time was prolonged, and consequently, the $\mathrm{pH}$ value increased more. However, no harmful effects of such $\mathrm{pH}$ values on algae were observed in this study.

The photosynthetic activity of algae was monitored by dissolved oxygen concentration. Similarly as for $\mathrm{pH}$, the values were increasing from the first day of the experiment. Regarding excessive concentrations of dissolved oxygen ( $>35 \mathrm{mg} / \mathrm{L}$ ) that could inhibit microalgal growth (Kumar and Das 2012; Su et al. 2012), no such effect was noticed herein, as the values were between 4 and $26 \mathrm{mg} / \mathrm{L} \mathrm{O}$. However, strong correlation was observed between the dissolved oxygen and photosynthetic activity with illumination. As most algae assimilate nutrients more rapidly in the light than in the dark, sufficient illumination is highly important. Nevertheless, in order to achieve real conditions, no additional illumination was provided.

\section{Comparison between carbon sources}

Although several carbon sources support heterotrophic growth of Chlorella, glucose and acetate are still one of the 
Table 2 Comparison between selected carbon sources $(0.25 \mathrm{~g} / \mathrm{L}$ of substrate) in regard to nitrate removal efficiency by alginate-immobilised $C$. sorokiniana at three different initial nitrate concentrations $(20,50$ and $100 \mathrm{mg} / \mathrm{L})$

\begin{tabular}{|c|c|c|c|c|c|}
\hline \multirow[t]{3}{*}{$\gamma \mathrm{NO}_{3}^{-}(\mathrm{mg} / \mathrm{L})$} & \multirow{3}{*}{ C source } & \multicolumn{4}{|c|}{ Efficiency (\%) } \\
\hline & & \multicolumn{4}{|l|}{$t(\mathrm{~h})$} \\
\hline & & 24 & 48 & 72 & 96 \\
\hline \multirow[t]{3}{*}{20} & $\mathrm{~S} 1^{\mathrm{a}}$ & 62.71 & 82.75 & 96.31 & - \\
\hline & GB & 93.50 & 100 & - & - \\
\hline & $\mathrm{HB}$ & 98.29 & - & - & - \\
\hline \multirow[t]{3}{*}{50} & $\mathrm{~S} 2^{\mathrm{a}}$ & 39.31 & 75.20 & 92.55 & - \\
\hline & GB & 59.88 & - & 98.70 & - \\
\hline & HB & 51.69 & 94.02 & - & - \\
\hline \multirow[t]{3}{*}{100} & $\mathrm{~S} 2^{\mathrm{a}}$ & 27.02 & - & 76.35 & 88.22 \\
\hline & GB & 39.48 & - & 97.74 & 100 \\
\hline & $\mathrm{HB}$ & 41.43 & 84.78 & 98.51 & - \\
\hline
\end{tabular}

The beads-to-water ratio was 1:6.7

${ }^{\text {a }} 0.5 \mathrm{~g} / \mathrm{L}$ of substrate (1:10 beads/water)

most used supplements (Kumar and Das 2012; Zheng et al. 2013). However, concerning the performed experiments, the carbon sources used in this study have shown impressive results in relation to support microalgae growth and nutrients' removal. The comparison between selected carbon sources is shown in Table 2. Sucrose proved to be the least effective of the tested carbon sources, as the nitrate efficiencies were the lowest amongst all. Otherwise, the nitrate removal efficiencies in the case of acacia honey and grape juice were highly comparable, and therefore, both carbon sources could be suitable for this specific purpose. Except in the case of grape juice, the water sample had slightly greater turbidity.

At an initial nitrate concentration of $20 \mathrm{mg} / \mathrm{L}$ in the presence of grape juice or honey, nitrate could be removed from drinking water in 1 day in more than $90 \%$. However, with increasing nitrate concentration, the removal time increases. At $100 \mathrm{mg} / \mathrm{L}$ of initial nitrate, nitrate could be removed in 3 days in more than $95 \%$ of cases. The explanation for the good performances of these substrates (i.e. grape juice and honey) in contrast to sucrose comes from the various substances they contain, which contribute to $C$. sorokiniana growth and positively affect its metabolism, and consequently enhances the nitrate removal. Similar has already been found for one of another natural carbon sources, i.e. molasses (Huang et al. 2011; Vidotti et al. 2014).

\section{Removal of COD}

Due to the addition of an external carbon source to the water sample, the COD concentrations were monitored. The results for COD removal efficiency of the selected samples at $100 \mathrm{mg} / \mathrm{L}$ of initial nitrate concentration are collated in Fig. 5a. In all samples, the beads-to-water ratio was 1:6.7, except for the sucrose sample (S2), the ratio of which was 1:10. The fastest removal rates were detected when honey and grape juice were used as carbon sources, whilst the assimilation of sucrose was more complex and the removal time was longer. It could be concluded that algae prefer to assimilate honey and grape juice before sucrose. At the initial concentration of substrate $0.5 \mathrm{~g} / \mathrm{L}$, $50-60 \%$ of the substrate was removed after 4 days (at an initial nitrate concentration of $100 \mathrm{mg} / \mathrm{L}$ ). At lower substrate concentrations, even higher removal efficiencies were achieved, up to $80 \%$.

However, some correlations could also be found between COD removal efficiency and the initial nitrate concentration. Kim et al. (2013a) reported that increasing the nitrate or ammonium concentrations resulted in increased glucose removal efficiency. The results of this research (data not shown) could also support this in some way, particularly if the highest and lowest nitrate concentrations are compared, otherwise the differences are smaller. However, the removal times at higher nitrate concentrations are also longer, and higher amounts of COD could be consumed by algae.

The influence of bead concentration on COD removal was accompanied in the experiments with acacia honey at an initial substrate concentration of $0.25 \mathrm{~g} / \mathrm{L}$, whereby two different concentrations of beads were tested. The beads/ water ratios for sample HA and sample HB were set at 1:4 and 1:6.7, respectively. Those experiments were performed at 50 as well as at $100 \mathrm{mg} / \mathrm{L}$ of initial nitrate (Fig. 5b), and the same experimental procedure as in the previous experiments was used. Contrary to expectations, the results indicated that the number of beads did not impact so expressively on COD removal neither at $50 \mathrm{mg} / \mathrm{L}$ of initial nitrate nor at $100 \mathrm{mg} / \mathrm{L}$. Just occasional increases in consumption were observed in those samples with higher bead concentrations (samples A). This was also confirmed in the experiments with grape juice. Similar observations were reported by Tam and Wong (2000), and they argued that the reduction of COD was mainly due to physical adsorption of organic matter onto the alginate gel and that algae had limited roles in COD removal. However, the efficiency of COD removal after 3 days of operation at $100 \mathrm{mg} / \mathrm{L}$ of nitrate in this experiment was above $70 \%$, and the final COD concentrations were around $10-15 \mathrm{mg} / \mathrm{L} \mathrm{O}_{2}$.

\section{The impact of the amount of biosorbent}

The nutrient removal rates are connected to the cell mass, and high algal concentrations could improve the efficiency and shorten the retention time (Tam and Wong 2000). The treatment efficiency in the immobilised systems is, next to the cell concentration, also affected by the 

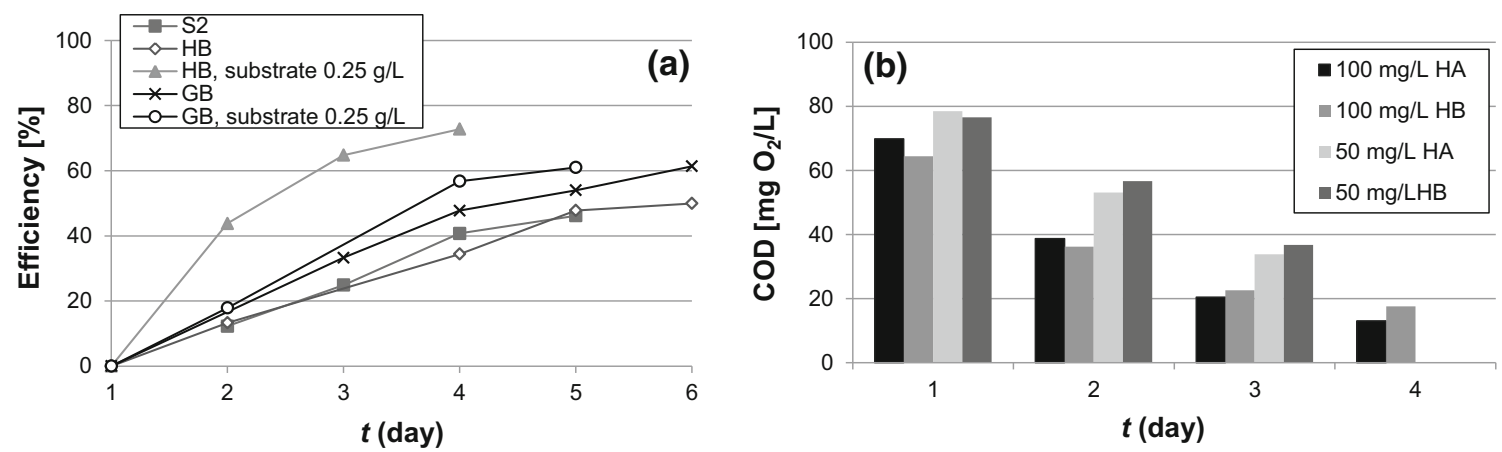

Fig. 5 COD removal efficiency when using different carbon sources at $100 \mathrm{mg} / \mathrm{L}$ of initial nitrate concentration (a). b Impact of bead concentration on COD removal during the experiments with acacia honey

Table 3 Effect of algal bead concentration on the nitrate removal efficiency

\begin{tabular}{|c|c|c|c|c|c|c|}
\hline \multirow[t]{3}{*}{$\gamma \mathrm{NO}_{3}{ }^{-}[\mathrm{mg} / \mathrm{L}]$} & \multirow{3}{*}{ Sample ${ }^{\mathrm{a}}$} & \multicolumn{5}{|c|}{ Efficiency (\%) } \\
\hline & & \multicolumn{5}{|l|}{$t(\mathrm{~h})$} \\
\hline & & 24 & 48 & 72 & 96 & 120 \\
\hline \multirow[t]{2}{*}{50} & GA & 62.28 & 96.01 & - & - & - \\
\hline & GB & 68.78 & 99.33 & - & - & - \\
\hline \multirow[t]{2}{*}{100} & GA & - & 55.67 & 76.47 & 91.19 & 98.01 \\
\hline & GB & - & 71.25 & 99.09 & 100 & 100 \\
\hline \multirow[t]{2}{*}{50} & HA & 79.62 & 90.72 & 99.11 & - & - \\
\hline & $\mathrm{HB}$ & 69.74 & 86.17 & 99.26 & - & - \\
\hline \multirow[t]{2}{*}{100} & HA & 55.57 & - & 90.91 & 98.33 & 99.90 \\
\hline & HB & 23.91 & - & 85.67 & 96.89 & 99.66 \\
\hline
\end{tabular}

The results for grape juice and honey are represented at substrate concentrations of $0.5 \mathrm{~g} / \mathrm{L}$

${ }^{a}$ Beads/water ratio for each sample: GA 1:10, GB 1:6.7, HA 1:4, HB $1: 6.7$

numbers of immobilised algal beads in the water. Therefore, the impact of microalgal bead concentrations, i.e. the quantity of used biosorbent on the nitrate removal efficiency, is shown in Table 3. Either the honey or the grape juice was used in the experiment, and the amount of biosorbent played an important role. In the case of grape juice, sample A with the lowest bead concentration (beads/water 1:10) gave apparently poorer results than sample B with higher amounts of beads at both carbon concentrations. However, in Table 3, only the results for $0.5 \mathrm{~g} / \mathrm{L}$ substrate are shown. Thus, an insufficient quantity of algal beads reduced the nitrate removal efficiency. The difference in the removal efficiency was the more noticeable at the highest initial nitrate concentration. Similarly it could be argued that for the experiments with acacia honey, sample B contained the same amount of beads as were used in sample B of the experiment with grape juice. Although the best removal rates were obtained at the maximum bead concentration (honey, sample A), it could be concluded that sufficient removal of nitrate could be achieved at a beads-to-water ratio of 1:6.7 or smaller. However, the appropriate amount of beads reported for ensuring sufficient nutrients removal in one on the previous studies was 3.8 beads $/ \mathrm{mL}$ of wastewater (Tam and Wong 2000), and in another research, this concentration was even lower ( 2.6 beads/ $\mathrm{mL}$ ) (Ruiz-Marin et al. 2010). The results obtained support these findings, as the number of beads used for effective removal in this study were close to those values. However, continuously increasing algal biomass and bead concentration will not necessarily result in significant improvement of nutrient removal. Excessive amounts of beads could lead to a self-shading effect that could restrict the algae growth (Ruiz-Marin et al. 2010). At the highest beads concentration used herein, no signs of self-shading effect were observed, although mixing within a reactor was not provided for the entire time. However, it was found that microalgae activity was in high correlation with outside conditions, as several days of reduced sun illumination strongly decreased the microalgae activity. Consequently, this was reflected in the dissolved oxygen concentrations and also $\mathrm{pH}$ values, as already mentioned.

\section{The beads' ages}

A study on the influences of beads' ages on nitrate removal efficiency is shown in Table 4. Sample B served as reference. In the experiments with $0.5 \mathrm{~g} / \mathrm{L}$ of grape juice, the results for sample $\mathrm{C}$ with old beads were far away from those for fresh beads (sample A). A similar tendency was found with $0.25 \mathrm{~g} / \mathrm{L}$ of grape juice and $100 \mathrm{mg} / \mathrm{L}$ of initial nitrate, but the efficiency decreased even more. The beads were therefore discarded as the operation was no longer viable. Compared with the new beads, the old beads were apparently softer, the strength of the alginate matrix was affected, and leaking of the cells was observed in the water. The instabilities of alginate beads occur when they come in 
Table 4 Influence of beads age on nitrate removal efficiency: sample B represents new beads, whilst sample C beads of aged 4-5 weeks

\begin{tabular}{|c|c|c|c|c|c|c|c|}
\hline \multirow[t]{3}{*}{ Carbon source $(\mathrm{g} / \mathrm{L})$} & \multirow[t]{3}{*}{$\gamma \mathrm{NO}_{3}^{-}(\mathrm{mg} / \mathrm{L})$} & \multirow{3}{*}{ Sample } & \multicolumn{5}{|c|}{ Efficiency $(\%)$} \\
\hline & & & \multicolumn{5}{|l|}{$t(\mathrm{~h})$} \\
\hline & & & 24 & 48 & 72 & 96 & 120 \\
\hline \multirow[t]{4}{*}{0.5} & \multirow[t]{2}{*}{50} & GB & 68.78 & 99.33 & - & - & - \\
\hline & & $\mathrm{GC}$ & 10.90 & 30.32 & - & - & - \\
\hline & \multirow[t]{2}{*}{100} & GB & - & 71.25 & 97.76 & 100 & 100 \\
\hline & & GC & - & 33.35 & 50.19 & 62.79 & 71.92 \\
\hline \multirow[t]{2}{*}{0.25} & \multirow[t]{2}{*}{100} & GB & 39.48 & - & 97.74 & 100 & - \\
\hline & & GC & 11.85 & - & 29.81 & 41.79 & - \\
\hline
\end{tabular}

Two different concentrations of grape juice tested were 0.5 and $0.25 \mathrm{~g} / \mathrm{L}$

contact with cations that serve as chelating agents and antigelling cations, such as dissolved phosphorus, EDTA citrates, sodium bicarbonate and so on. Moreover, bacteria naturally existing in the waters, such as some heterotrophic bacteria, could form a thick film on the surface of the alginate beads and degrade them (Cruz et al. 2013).

However, several cycles, which means up to 2 months of experiments, were efficiently implemented with one series of beads. The degradation of beads was relatively low as no external phosphorus was used and the initial water sample, i.e. the drinking water, was relatively pure, as bicarbonate is permanently found in the water.

Removal of ammonium in the presence of nitrate

Removal of ammonium at an initial concentration of approximately $10 \mathrm{mg} / \mathrm{L}$ and in the presence of nitrate is shown in Fig. 6a, b. It could be seen that algae preferred to assimilate ammonium before nitrate, which was in accordance with the previous papers (Li et al. 2011; Su et al. 2012). The answer for ammonium preference is in the different nitrogen uptake mechanisms of microalgae that differ regarding nitrogen sources. As ammonium is absorbed directly into the cells and then transformed into amino acids, less energy is required for its uptake than for nitrate (Kim et al. 2013a). The enzymes responsible for ammonium assimilation under heterotrophic conditions are glutamine synthetase that produces glutamine (reaction 1) and glutamate synthase that produces two molecules of glutamate (reaction 2) (Khan and Yoshida 2008; Perez-Garcia et al. 2011b): $\begin{aligned} \text { ATP }+ \text { L-Glutamate }+ & \mathrm{NH}_{3} \rightarrow \\ & \text { ADP }+ \text { Orthophosphate } \\ & + \text { L-Glutamine }\end{aligned}$

L-Glutamine $+\alpha$-Ketoglutarate $+\mathrm{NADH}+\mathrm{H}^{+}$ $\rightarrow(2) \mathrm{L}-$ Glutamate $+\mathrm{NAD}^{+}$

In accordance with the above reactions, carbon skeletons in the form of keto acids and energy in the form of ATP and NADH are required for this process (Perez-Garcia et al. 2011a). Moreover, it was also reported that ammonium ions could interact with the carboxyl groups of the alginate beads (without microalgae) and chemically bound to it, which could also be reflected in the reduction of ammonium as they infiltrated continually through alginate into the cells (Ruiz-Marin et al. 2010).

However, the addition of honey enhanced the removals of both ammonium and nitrate, as even better results were achieved at $50 \mathrm{mg} / \mathrm{L}$ than at $20 \mathrm{mg} / \mathrm{L}$ of initial nitrate (Fig. 6c, d). The COD removal was slightly higher compared to previous experiments where only one nitrogen source was available and the COD removal efficiencies achieved were between 60 and $80 \%$. Ammonium was completely removed in 2 days and nitrate of more than $95 \%$ in 3 days. By increasing the initial ammonium concentration to $30 \mathrm{mg} / \mathrm{L}$ (Fig. 6e, f) at the same nitrate concentration (and the same beads/water ratio), the removal times of both ions increased, but the uptake mechanisms were quite similar (sample B). However, the best results were achieved with sample $C$ at beads/water ratio 1:5, with the ammonium being completely removed in $<3$ days and nitrate of $81.24 \%$ in 4 days, respectively. Lower nitrate efficiencies were expected because the nitrate transporter and the enzymes required for nitrate reduction could have been inhibited and deactivated by the ammonium assimilation when both nitrate and ammonium were in the water (Zheng et al. 2013). Therefore, the removal rates of ammonium were higher than the nitrate, as already mentioned in one of the studies (Kim et al. 2013b). On the other hand, the nitrite concentrations on the fourth day were still high, and efficient reduction was required over additional time.

The $\mathrm{pH}$ values in the experiments with ammonium were varied from 6.58 up to 9.55. A similar trend for the increase in $\mathrm{pH}$ values was noticed as in those experiments performed only with nitrate, although by metabolising the ammonia, hydrogen ions may be produced, which could be reflected in decreasing $\mathrm{pH}$. The reason is the high nitrate 

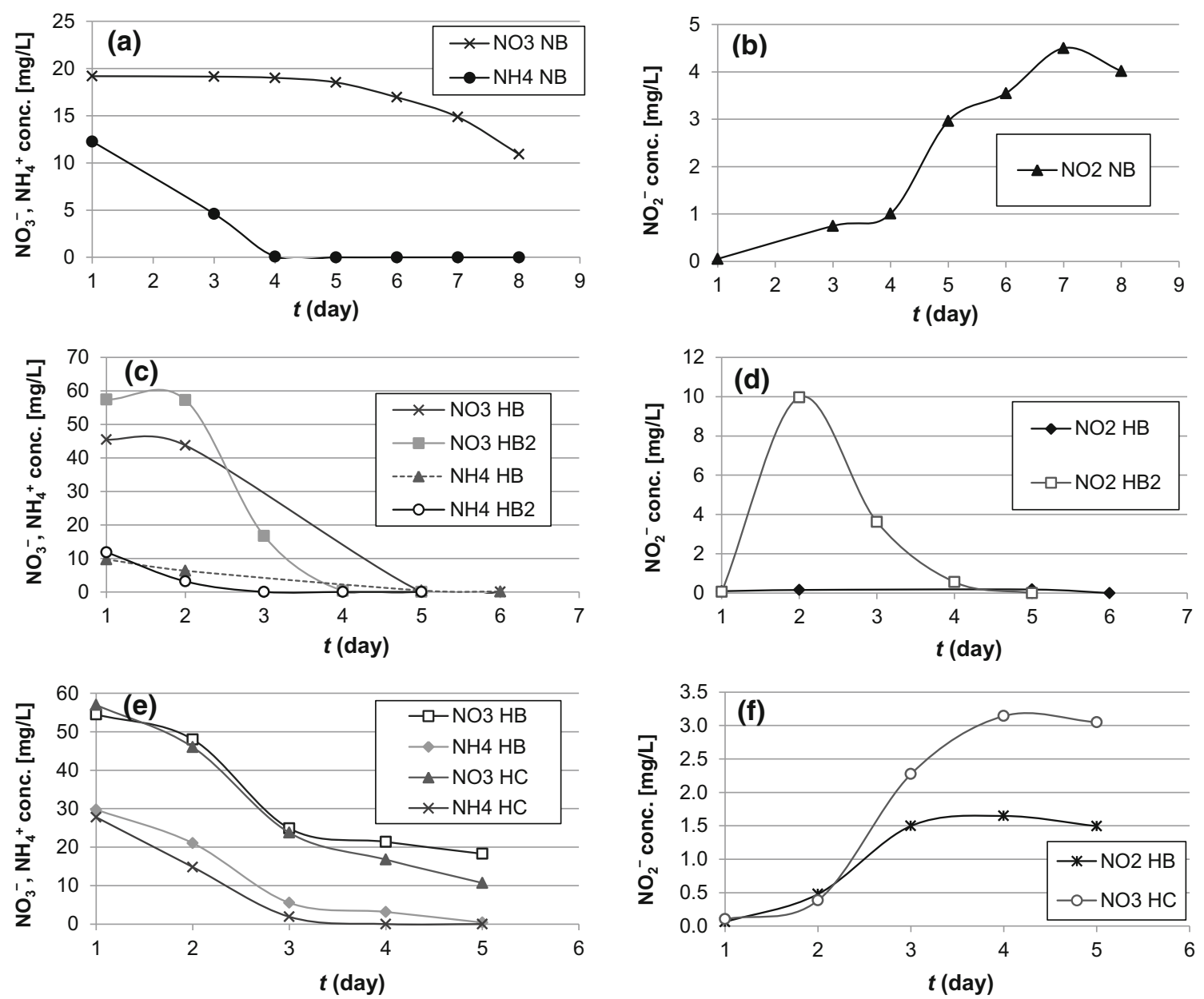

Fig. 6 Removal of ammonium in the presence of nitrate. a, b Results when no external carbon source was added, c-f experiment's results with acacia honey (sample B beads/water ratio of 1:6.7, sample $C$ ratio of 1:5)

concentration as higher amounts of nitrate in the water increased the $\mathrm{pH}$ more than the ammonium decreased it. The variations in $\mathrm{pH}$ values are also possible due to the cultivation under the mixotrophic regime, whereas both hydroxyl and $\mathrm{CO}_{2}$ could be produced which influences the pH (Kim et al. 2013a).

In conclusion, alginate-immobilised $C$. sorokiniana was efficiently applied in removal of nitrogen sources from drinking water samples, i.e. nitrate and ammonium. The removal efficiencies were highly dependent on the presence of appropriate carbon source. The alternative carbon sources, grape juice and acacia honey, were shown to be more relevant carbon sources than the conventionally used sucrose. The complete removals of above-mentioned pollutants could be achieved under properly chosen experimental conditions.

The results for ammonium (Fig. 6e) are close to those by Tam and Wong (2000), where complete removal of ammonium with a concentration of $30 \mathrm{mg} / \mathrm{L}$ was achieved within $24 \mathrm{~h}$ of incubation by $C$. vulgaris entrapped in Ca- alginate. But it must be considered that in the experiments performed herein, ammonium and nitrate both were at the disposal; therefore, removal times could be longer and efficiencies could be lower. However, when $C$. vulgaris was cultured on wastewaters with ammonium concentration of $155 \mathrm{mgNH}_{4}-\mathrm{N} / \mathrm{L}$, the removal efficiency after $48 \mathrm{~h}$ was only $55 \%$ (Khan and Yoshida 2008). The removal of ammonium by the same species growing in batch cultures of urban wastewater resulted in efficiencies between 60 and $80 \%$ (Ruiz-Marin et al. 2010). Otherwise, lower ammonium removal rates for $C$. sorokiniana than obtained herein were noticed in some other research. For immobilised cells, removal rates of 43.59 and $41.46 \%$ were found, under heterotrophic and microaerobic conditions, respectively (Liu et al. 2012). In a certain study on the effect of nitrogen concentration on $C$. sorokiniana growth, nitrate concentration of $80 \mathrm{mgNO}_{3}-\mathrm{N} / \mathrm{L}$ provided a removal efficiency of $67 \%$, whilst an ammonia concentration of $40 \mathrm{mgNH}_{3}-\mathrm{N} / \mathrm{L}$ provided around $100 \%$ (Kim et al. 2013b). On the other hand, co-immobilisation of $C$. vulgaris or $C$. sorokiniana 
with a microalgae growth-promoting bacterium Azospirillum brasilense reached removal of only $15 \%$ of nitrate but up to $100 \%$ ammonium within 6 days, whilst microalgae alone gave even lower efficiencies (de-Bashan et al. 2004). In de-Bashan et al.'s (2008) research, immobilised $C$. sorokiniana or co-immobilised with Azospirillum brasilense efficiently reduced ammonium from wastewater in 4 days, wherein the ammonium concentration was the same as in this study $\left(10 \mathrm{mg} / \mathrm{L} \mathrm{NH}_{4}\right)$. Regarding nitrate removal, Chlorella sp. showed a nitrate uptake rate of up to $84.11 \%$ in 14 days when treating urban wastewater with an initial concentration of $190 \mathrm{mgNO}_{3}-\mathrm{N} / \mathrm{L}$ (Rasoul-Amini et al. 2014). In another research, microalgae species Chlorella sp., C. vulgaris, S. quadricauda and S. dimorphus tested in batch reactors fed with wastewater were able to remove nitrate $(70 \mathrm{mg} / \mathrm{L})$ and nitrite $(18 \mathrm{mg} / \mathrm{L})$ after 3 days between $43-54 \%$ and 83-95\%, respectively (Singh and Thomas 2012). In one of the rare studies on drinking water, S. obliquus cells adsorbed in hydrophilic polymeric foams achieved nitrate removal efficiency of around $100 \%$, whereas a continuous-flow bioreactor was fed with water containing $50 \mathrm{mgN}$ ions/L (Urrutia et al. 1995).

\section{Conclusion}

The experiments performed with alginate-immobilised $C$. sorokiniana showed that this algae species in the presence of each selected carbon source efficiently removed nitrate from drinking water samples (at 20,50 and $100 \mathrm{mg} / \mathrm{L}$ initial nitrate concentrations tested). The nutrients removals were highly dependent on environmental factors including light intensity and the carbon and nitrogen sources' availabilities. The presence of natural carbon sources positively affected the algae and its metabolism. Grape juice and acacia honey were superior to sucrose for the removal of nitrate. When both ammonium and nitrate were present in the water, the algae preferred to assimilate ammonium in advance of nitrate; therefore, the nitrate removal time was prolonged. Otherwise, the ammonium at an initial concentration of $30 \mathrm{mg} / \mathrm{L}$ was completely removed in $<3$ days. No drastic decrease in $\mathrm{pH}$ was noticed when ammonium was used as carbon source, due to its combination with nitrate. The amount of biosorbent used importantly affected the nitrate and ammonium removal efficiencies. The beads/water ratio of 1:6.7 (v/v) was found to be adequate for achieve sufficient efficiencies. The complete removals of nitrate and ammonium ions could be achieved with alginate-immobilised $C$. sorokiniana.
Acknowledgments The authors would like to acknowledge the Slovenian Research Agency for the financial support (Project No. 1000-11-310131).

\section{References}

Abdel Hameed MS (2007) Effect of algal density in bead, bead size and bead concentrations on wastewater nutrient removal. Afr $\mathbf{J}$ Biotechnol 6(10):1185-1191

Abdel-Raouf N, Al-Homaidan AA, Ibraheem IBM (2012) Microalgae and wastewater treatment. Saudi J Biol Sci 19:257-275. doi:10. 1016/j.sjbs.2012.04.005

Awasthi M (2005) Nitrate reductase activity: a solution to nitrate problems tested in free and Immobilized algal cells in presence of heavy metals. Int J Environ Sci Technol 2:201-206. doi:10. 1007/bf03325876

Bischoff H, Bold HC (2003) Psychological studies IV. In: Some soil algae from enchanted rock and related algal species, vol 6318 . University Texas Publications

Bizaj E (2006) The influence of grape juice composition on the alcoholic fermentation course. Biotechnical Faculty, Department of Food Science and Technology, University of Ljubljana, Ljubljana

Božnar A (2003) Microbiology of honey. V: microbiology of foodstuffs. University of Ljubljana, Biotechnical Faculty, Department of Food Science and Technology, Ljubljana

Christenson L, Sims R (2011) Production and harvesting of microalgae for wastewater treatment, biofuels, and bioproducts. Biotechnol Adv 29:686-702. doi:10.1016/j.biotechadv.2011.05. 015

Cruz I, Bashan Y, Hernàndez-Carmona G, de-Bashan LE (2013) Biological deterioration of alginate beads containing immobilized microalgae and bacteria during tertiary wastewater treatment. Appl Microbiol Biotechnol 97:9847-9858. doi:10.1007/ s00253-013-4703-6

de-Bashan LE, Bashan Y (2010) Immobilized microalgae for removing pollutants: review of practical aspects. Bioresour Technol 101:1611-1627. doi:10.1016/j.biortech.2009.09.043

de-Bashan LE, Hernandez J-P, Morey T, Bashan Y (2004) Microalgae growth-promoting bacteria as "helpers" for microalgae: a novel approach for removing ammonium and phosphorus from municipal wastewater. Water Res 38:466-474. doi:10.1016/j. watres.2003.09.022

de-Bashan LE, Trejo A, Huss VAR, Hernandez J-P, Bashan Y (2008) Chlorella sorokiniana UTEX 2805, a heat and intense, sunlighttolerant microalga with potential for removing ammonium from wastewater. Bioresour Technol 99:4980-4989. doi:10.1016/j. biortech.2007.09.065

DIN 38 406-E5-1 (1983) Photometric determination of ammonium nitrogen by sodium dichloroisocyanurate and sodium salicylate. DIN-German Institute for Standardization, Berlin, Germany

Gao C, Zhai Y, Ding Y, Wu Q (2010) Application of sweet sorghum for biodiesel production by heterotrophic microalga Chlorella protothecoides. Appl Energy 87:756-761. doi:10.1016/j. apenergy.2009.09.006

Hernandez J-P, de-Bashan LE, Bashan Y (2006) Starvation enhances phosphorus removal from wastewater by the microalga Chlorella spp. co-immobilized with Azospirillum brasilense. Enzym Microb Technol 38:190-198. doi:10.1016/j.enzmictec.2005.06.005

Huang L, Xiang Y, Cai J, Jiang L, Lv Z, Zhang Y, Xu Z (2011) Effects of three main sugars in cane molasses on the production of butyric acid with Clostridium tyrobutyricum. Korean J Chem Eng 28:2312-2315 
ISO 6777:1984 (1984) Water quality-determination of nitritemolecular absorption spectrometric method. International Organization of Standardization, Geneva

ISO 7890-1:1986 (1986) Water quality-determination of nitratepart 1: 2,6-Dimethylphenol spectrometric method. International Organization of Standardization, Geneva

ISO 8467:1993 (1993) Water quality—determination of permanganate index. International Organization of Standardization, Geneva

Kaonga CC, Chiotha SS, Monjerezi M, Fabiano E, Henry EM (2008) Levels of cadmium, manganese and lead in water and algae; Spirogyra aequinoctialis. Int J Environ Sci Technol 5:471-478. doi:10.1007/bf03326043

Khan M, Yoshida N (2008) Effect of L-glutamic acid on the growth and ammonium removal from ammonium solution and natural wastewater by Chlorella vulgaris NTM06. Bioresour Technol 99:575-582. doi:10.1016/j.biortech.2006.12.031

Kim S, Lee Y, Hwang S-J (2013a) Removal of nitrogen and phosphorus by Chlorella sorokiniana cultured heterotrophically in ammonia and nitrate. Int Biodeterior Biodegrad 85:511-516. doi:10.1016/j.ibiod.2013.05.025

Kim S, Park J-E, Cho Y-B, Hwang S-J (2013b) Growth rate, organic carbon and nutrient removal rates of Chlorella sorokiniana in autotrophic, heterotrophic and mixotrophic conditions. Bioresour Technol 144:8-13. doi:10.1016/j.biortech.2013.06.068

Kumar K, Das D (2012) Growth characteristics of Chlorella sorokiniana in airlift and bubble column photobioreactors. Bioresour Technol 116:307-313. doi:10.1016/j.biortech.2012.03.074

Leesing R, Kookkhunthod S (2011) Heterotrophic growth of Chlorella sp. KKU-S2 for lipid production using molasses as a carbon substrate. In: International conference on food engineering and biotechnology, IPCBEE vol 9, pp 87-91

Li Y et al (2011) Characterization of a microalga Chlorella sp. well adapted to highly concentrated municipal wastewater for nutrient removal and biodiesel production. Bioresour Technol 102:5138-5144. doi:10.1016/j.biortech.2011.01.091

Liu K, Li J, Qiao H, Lin A, Wang G (2012) Immobilization of Chlorella sorokiniana GXNN 01 in alginate for removal of $\mathrm{N}$ and P from synthetic wastewater. Bioresour Technol 114:26-32. doi:10.1016/j.biortech.2012.02.003

Lizzul AM, Hellier P, Purton S, Baganz F, Ladommatos N, Campos L (2014) Combined remediation and lipid production using Chlorella sorokiniana grown on wastewater and exhaust gases. Bioresour Technol 151:12-18. doi:10.1016/j.biortech.2013.10.040

Mallick N (2002) Biotechnological potential of immobilized algae for wastewater $\mathrm{N}, \mathrm{P}$ and metal removal: a review. BioMetals 15(4):377-390

Mane PC, Bhosle AB (2011) Bioremoval of some metals by living algae Spirogyra sp. and Spirullina sp. from aqueous solution. Int J Environ Res 6(2):571-576

Mehta SK, Gaur JP (2001) Removal of $\mathrm{Ni}$ and $\mathrm{Cu}$ from single and binary metalsolutions by free and immobilized Chlorella vulgaris. Eur J Protistol 37:261-271. doi:10.1078/0932-4739-00813

Moreno-Garrido I (2008) Microalgae immobilization: current techniques and uses. Bioresour Technol 99:3949-3964. doi:10.1016/ j.biortech.2007.05.040

Ngangkham M, Kumar Ratha S, Prasanna R, Saxena AK, Dhar DW, Sarika C, Narayana Prasad RB (2012) Biochemical modulation of growth, lipid quality and productivity in mixotrophic cultures of Chlorella sorokiniana. Springer Plus 1:33

Nussinovitch A (ed) (2010) Polymer macro- and micro-gel beads: fundamentals and applications, XXV edn. Springer, Berlin

Olguín EJ, Sánchez-Galván G, González-Portela RE, López-Vela M (2008) Constructed wetland mesocosms for the treatment of diluted sugarcane molasses stillage from ethanol production using Pontederia sagittata. Water Res 42:3659-3666. doi:10. 1016/j.watres.2008.05.015
Perez-Garcia O, Bashan Y, Puente ME (2011a) Organic carbon supplementation of sterilized municipal wastewater is essential for heterotrophic growth and removing ammonium by the microalga Chlorella vulgaris. J Phycol 47:190-199. doi:10.1111/ j.1529-8817.2010.00934.x

Perez-Garcia O, Escalante FME, de-Bashan LE, Bashan Y (2011b) Heterotrophic cultures of microalgae: metabolism and potential products. Water Res 45:11-36. doi:10.1016/j.watres.2010.08.037

Prathima Devi M, Swamy YV, Venkata Mohan S (2013) Nutritional mode influences lipid accumulation in microalgae with the function of carbon sequestration and nutrient supplementation. Bioresour Technol 142:278-286. doi:10.1016/j.biortech.2013.05.001

Qiao H, Wang G, Zhang X (2009) Isolation and characterization of Chlorella sorokiniana GXNN01 (Chlorophyta) with the properties of heterotrophic and microaerobic growth. J Phycol 45:1153-1162

Rashid N, Lee K, Han J, Gross M (2013) Hydrogen production by immobilized Chlorella vulgaris: optimizing $\mathrm{pH}$, carbon source and light. Bioprocess Biosyst Eng 36:867-872. doi:10.1007/ s00449-012-0819-9

Rasoul-Amini S et al (2014) Removal of nitrogen and phosphorus from wastewater using microalgae free cells in bath culture system. Biocatal Agric Biotechnol 3:126-131. doi:10.1016/j. bcab.2013.09.003

Riaño B, Hernández D, García-González MC (2012) Microalgalbased systems for wastewater treatment: effect of applied organic and nutrient loading rate on biomass composition. Ecol Eng 49:112-117. doi:10.1016/j.ecoleng.2012.08.021

Ruiz-Marin A, Mendoza-Espinosa LG, Stephenson T (2010) Growth and nutrient removal in free and immobilized green algae in batch and semi-continuous cultures treating real wastewater. Bioresour Technol 101:58-64. doi:10.1016/j.biortech.2009.02.076

Shi X-M, Zhang X-W, Chen F (2000) Heterotrophic production of biomass and lutein by Chlorella protothecoides on various nitrogen sources. Enzym Microb Technol 27:312-318. doi:10. 1016/S0141-0229(00)00208-8

Singh G, Thomas PB (2012) Nutrient removal from membrane bioreactor permeate using microalgae and in a microalgae membrane photoreactor. Bioresour Technol 117:80-85. doi:10. 1016/j.biortech.2012.03.125

Su Y, Mennerich A, Urban B (2012) Comparison of nutrient removal capacity and biomass settleability of four high-potential microalgal species. Bioresour Technol 124:157-162. doi:10.1016/j. biortech.2012.08.037

Sun N, Wang Y, Li Y-T, Huang J-C, Chen F (2008) Sugar-based growth, astaxanthin accumulation and carotenogenic transcription of heterotrophic Chlorella zofingiensis (Chlorophyta). Process Biochem 43:1288-1292. doi:10.1016/j.procbio.2008.07.014

Tam NFY, Wong YS (2000) Effect of immobilized microalgal bead concentrations on wastewater nutrient removal. Environ Pollut 107:145-151. doi:10.1016/S0269-7491(99)00118-9

Tanner W (2000) The Chlorella hexose/H(+)-symporters. Int Rev Cytol 200:101-141

Urrutia I, Serra JL, Llama MJ (1995) Nitrate removal from water by Scenedesmus obliquus immobilized in polymeric foams. Enzym Microb Technol 17:200-205. doi:10.1016/0141-0229(94)00008-F

Vidotti ADS, Coelho RS, Franco LM, Franco TT (2014) Miniaturized culture for heterotrophic microalgae using low cost carbon sources as a tool to isolate fast and economical strains. Chem Eng Trans 38:325-330

Zheng Y, Li T, Yu X, Bates PD, Dong T, Chen S (2013) High-density fed-batch culture of a thermotolerant microalga Chlorella sorokiniana for biofuel production. Appl Energy 108:281-287. doi:10.1016/j.apenergy.2013.02.059 